REVIJA ZA ELEMENTARNO IZOBRAŽEVANJE

JOURNAL OF ELEMNTARY EDUCATION

Vol. 13, No. 2, pp. 113-130, junij 2020

\title{
LEARNING ENVIRONMENT VARIABLES AND THE EFFICACY OF STUDENT LEARNING IN SECONDARY SCHOOL IN ABAK LOCAL GOVERNMENT, AKWA IBOM STATE
}

Abisola Oladeni SAKIRUdeEN ${ }^{1}$, EkANEM Uwe ${ }^{2}$

Potrjeno/Accepted

8. 4. 2020

Objavljeno/Published 8. 6.2020

Keywords:

Learning, Environment, Learning Effectiveness, Students', Variables

Ključne besede: učenje, okolje, učna učinkovitost, učenci, spremenljivke

UDK/UDC

373.5.091.3(669.158)

\author{
${ }^{1}$ University of Uyo, Faculty of Education, Akwa Ibom State, Nigeria \\ ${ }^{2}$ University of Calabar, Faculty of Education, Cross River State, Nigeria \\ CORRESPONDING AUTHOR/KORESPONDENČNI AVTOR/ \\ abisola4u@gmail.com
}

\begin{abstract}
Izvleček Four research questions and four null hypotheses were formulated to guide the study. A simple random sampling technique was used in selecting 34 respondents from each 6 schools, with a sample size of 204 was selected from the population of 1,518. The instrument titled LEVSLEQ was used to elicit response from the respondent. The reliability of the research instrument yielded a co-efficient of 0.82 . The data was analyzed using dependent t-test and was tested at .05 level of significance. The findings indicated that environmental variable studied influence students' learning effectiveness.

Spremenljivke učnega okolja in učinkovitost učenja srednješolcev $\mathbf{v}$ lokalni skupnosti Abak, država Akwa

Za usmerjanje raziskave smo oblikovali štiri ničelne hipoteze. Iz vsake od 6 šol smo s tehniko enostavnega naključnega vzorčenja izbrali po 34 respondentov in tako iz populacije 1518 učencev pridobili vzorec z 204 učenci. Za pridobitev odziva od respondentov je bil uporanljen instrument imenovan LEVSLEQ. Zanesljivost raziskovalnega instrumenta je dala koeficient 0,82 . Podatke smo analizirali $z$ uporabo t-testa za odvisne vzorce in preizkusili na ravni značilnosti $\mathrm{v}$ višini 0,05 . Ugotovitve so pokazale, $\mathrm{da}$ okoljske spremenljivke vplivajo na učno učinkovitost učencev.
\end{abstract}




\section{Introduction}

Education is the process in which an individual acquires physical and social capabilities demanded by the society in which he/she is born into, so as to be useful and contribute to the development of the society at large. Education is the most important component of human resource development and is accorded a pride in many countries for developmental activities. There is no doubt that the importance of education cannot be overstated because there is no country that has succeeded without educating its people. Education is an instrument for the acquisition of appropriate skills, ability and competence both mental and physical also as equipment for individual to live and contribute to the development of his/her society (Lawal, 2003).

Learning environment has been defined in many ways by many authors a few decades ago, in relation to where effective academic learning can take place. Environment is defined by Freiberg (1999) as an aspect of the filed in which an individual functions. Academic environment therefore means a place where academic instructions are given by teachers to the learners and physical plants; faculty relations; leadership and decision making; environment that is welcoming and conducive for learning; environment that promotes communication and interactions; environment that promotes a sense of belonging and self-esteem and the environment that promotes learning and self-fulfillment which can make an individual face later academic tasks (Cotton, 2001).

Teaching and learning is a complex task which involves the process of bringing out from the learners the desirable change in behaviour through critical thinking. This process, however, does not take place in vacuum but in a structured environment to facilitate learning. Teachers need to ensure that their teaching techniques are effective so that their students are able to grasp what was being imparted to them during teaching and learning process.

It has been observed in the recent past that secondary school students in Nigeria are not living up to expectation in delivering quality results expected by the system. A lot of problems seem to be bedeviling the secondary school system there by making the system ineffective. Learning needs to be effectively impactful to students at every point in time when they are exposed to learning activities. 
Learning effectiveness in this context refers to the extent to which learners can accomplish their pre-determined objectives. Learning effectiveness transcends beyond students passing final examinations. It also encompasses students' attainment in other domains of learning (the affective and the psychomotor domains). According to Bandele (2002), these other domains, apart from having influence on the cognitive achievement, also make the beneficiary of the education system live a fulfilled life and contribute meaningfully to the development of the society. The author argued that any deviation from these goals is a deviation from government's policy on education.

Teaching-learning interactive feedback is necessary in evaluating the level of understanding among the learners. Teachers must interact meaningfully with learners during lesson period. According to Freiberg (1999) where there is no vibrant and observable interaction between the teachers and learner, it could be deduced that learning has not taken place. He also opines that efficient teachers can make difficulties subjects look simple and interesting to the learners to understand without much stress.

Lowestein (1972) summits that the study of neurology reveals that, classroom challenges and feedback such as demonstrating method, questioning, and answering between teachers and learners can stimulate effective learning when classroom size is larger enough to accommodate learning. Appropriate use of teaching methods as well as usage of appropriate teaching aids and instructional materials have been claimed to contribute essentially to stimulating learning environment in school setting (Fraser, 2002). When classroom is large, where is tendency for the teacher to go round and inspect learner's works. A teacher can easily demonstrate his lessons by using any type of teaching aids which will improve the learners' effectiveness.

Adequate learning facilities are necessary for promoting effective learning. According to Anderson (1993), facilities such as comfortable writing desks and seats, decent and sizeable classroom blocks which are properly ventilated and illuminated can stimulate the learners towards learning effectively. Effective learning cannot take place without adequate learning facilities. Accounting to Sunday (2008), adequate learning facilities in school include well equip science laboratories and computer laboratories, library resources, geographical garden, ventilated and well illuminated classrooms can improve the way in which learners learn. 
Slavin (1004) emphasizes that a school learning environment must be established at a noise free area, such environment should be carefully selected so that the students' attention may be not be distracted unnecessarily. School location needs to be large enough to accommodate games and sports recreation facilities for learners to interactive with in other to increase their psycho-motor skills. In another contribution any school that is located near market square is bound to suffer direct source of noise pollution. According to Denga (2002) who states that, the learners' attention is often drawn to where noise source is perceived and it causes distraction of concentration from effective reading activities. This is sometimes known as attention process by many educational learning psychologists. Noise becomes disturbing when its echo over-powers individuals' internal auditory barriers inside the inner ear system. In such cases the learners reading attention span get disturbed.

Based on these variables on students, there is need to examine the influence of learning environment variables on students learning effectiveness in Abak Local Government Area of Akwa Ibom State.

\section{Purpose of the study}

The main purpose of this study was to examine the influence of learning environment variables on students' learning effectiveness in Abak Local Government Area of Akwa Ibom State specifically, the study aimed at examining:

i. The effect of teacher-learners interactive feedback on students' learning effectiveness in secondary school.

ii. The effect of classroom size on students' learning effectiveness in secondary school.

iii. The impact of availability of learning facilities on students' learning effectiveness in secondary school.

iv. The impact of school location on students' learning effectiveness in secondary school. 


\section{Research Questions}

In this study, the following research questions were raised to guide the study.

i. Do teacher-learners' interactive feedback as a significant relationship on learning effectiveness of secondary school students?

ii. How does classroom size as a significant relationship with students' learning effectiveness of secondary school students?

iii. Is there any significant relationship between availability of learning facilities on students' learning effectiveness of secondary school students?

iv. Is there any significant relationship between school location on students' learning effectiveness of secondary school students?

\section{Research Hypotheses}

In this study, four null hypotheses were raised and tested at 0.05 level of significance

i. There is no significant relationship between teacher-learners' interactive feedback on students' learning effectiveness of secondary school students.

ii. There is no significant relationship between classroom size on students' learning effectiveness of secondary school students.

iii. There is no significant relationship between available learning facilities on students' learning effectiveness of secondary school students.

iv. There is no significant influence of relationship between school location on students' learning effectiveness of secondary school students.

\section{Significance of the study}

This study is one that is highly desirable and important as its findings would be useful to students', teachers, school administrators, government and to guidance counsellors that are interested in education. The findings in this study would be beneficial in the following ways: 
The result of this finding Would suggest ways in which classroom lesson could be made more interacting in order to encourage teacher-learners interactive feedback, Suggest ways in which new classroom blocks should be designed and equipped in order to promote students' learning effectiveness and also Suggest the types of classroom facilities, quality science and computer laboratory and library resources, to be provided in each public secondary school to and students' learning effectiveness.

The result of the study would be useful to school administrators and teachers by seeing the effect of making use of appropriate teaching aids for effective teaching and learning. It would also suggest to the government to build larger library blocks in each school, equip them, and employ active librarians to attend students. This would promote better study habits in the students. Also, the result of the study would be recommended to the government to always established schools at where there is least noise pollution. Finally, the result would suggest group counselling for secondary school students at regular bases on effective learning development.

\section{Methodology}

The researcher adopted the relational survey research design. This design enabled the researcher to reach out to selected secondary schools in the study area. It also allowed for investigation the extent of influence of teaching-learning interactive feedback, classroom size, available learning facilities as well as school location on learning effectiveness of secondary school students. With the use of this design, the researcher could select sample to present a population which was considered large. The sample of this study consisted of 204 Senior Secondary School Two (SS2) students would range from age 12-16 from six public secondary schools were randomly selected. In each sampled school, 34 students were selected to take part as respondents.

\section{Instrumentation}

The researcher developed an instrument for data collection called "learning environment variables and students learning effectiveness questionnaire (LEVSLEQ)". Experts in Test and Evaluation in the Department of Educational Foundation, Guidance and Counseling, Faculty of Education, University of Uyo, 
critically scrutinized the contents of the questionnaire. The validators effected necessary corrections on the draft copy before accepting it suitable for further procedures. The questionnaire comprised of two sections, A and B. Section A comprised of items on the personal data of the respondent while, section $\mathrm{B}$ comprised of 29 items on study habits, with a breakdown of five items teachinglearning interactive feedback six items on the classroom size, six items on available learning facilities, six items, school location, six items and five items on learning effectiveness. The instrument had a 4-point rating scale as follows: Strongly Agree $(\mathrm{SA})=4$, Agree $(\mathrm{A})=3$, Disagree $(\mathrm{D})=2$, Strongly Disagree $(\mathrm{SD})=1$.

\section{Result presentation}

Item-by-Item Analysis of Research Questions

Answer of Research 1: Items on Teacher-Learners' Interactive Feedback

Mean and standard deviation was used in answering this question; the result of the analysis is as presented in table 1 :

Table 1: Mean scores of the respondent on Teacher-Learners' Interactive Feedback $(N=204)$

\begin{tabular}{|c|c|c|c|c|c|c|c|c|}
\hline $\mathrm{S} / \mathrm{N}$ & Teacher-Learners' Interactive Feedback & SA & A & $\mathrm{D}$ & $\mathrm{SD}$ & M & $\mathrm{SD}$ & Remark \\
\hline 1. & $\begin{array}{l}\text { I think faster when the teacher throws } \\
\text { questions at me seeking answers. }\end{array}$ & 96 & 396 & 76 & 10 & 3.21 & 0.73 & Agreed \\
\hline 2. & $\begin{array}{l}\text { I sometimes feel uncertain of my answers to } \\
\text { teachers' questions during lesson interaction. }\end{array}$ & 72 & 348 & 106 & 17 & 3.14 & 0.60 & Agreed \\
\hline 3. & $\begin{array}{l}\text { Interactive learning challenged me in the } \\
\text { classroom. }\end{array}$ & 81 & 321 & 96 & 22 & 3.79 & 0.65 & Agreed \\
\hline 4. & $\begin{array}{l}\text { Teaching-learning interactions make lessons } \\
\text { becomes clearer and interesting. }\end{array}$ & 164 & 399 & 48 & 8 & 3.15 & 0.76 & Agreed \\
\hline 5. & $\begin{array}{l}\text { My calculations become faster when mental } \\
\text { sums are taught by my teacher. }\end{array}$ & 224 & 363 & 32 & 11 & 3.51 & 0.70 & Agreed \\
\hline \multirow[t]{2}{*}{6.} & $\begin{array}{l}\text { The entire class becomes dull when there is } \\
\text { no teaching-learning interaction during } \\
\text { lessons. }\end{array}$ & 248 & 354 & 28 & 10 & 3.92 & 0.62 & Agreed \\
\hline & Cluster Mean & & & & & 3.45 & 0.68 & \\
\hline
\end{tabular}

Data is Table 1 show the mean response of students on teaching-learning interactive. The mean score of 3.21 for item 1 indicates that the respondents agreed that they think faster when teacher throws question at them. The mean score of 3.14 for item 2 indicates that the respondents agreed that they feel uncertain when they were answered questions during teaching and learning. Item 3 with a mean score of 3.79 indicates that the respondents mostly agreed that class interaction challenges them. Item 4 with a mean score of 3.15 also indicates that the respondents agreed that class 
interaction between them and their teachers' makes lesson clearer and interesting. The mean score of 3.51 for item 5 indicates that the respondents agreed that when mental sums are taught calculations becomes faster to them. Item 6 with a mean score of 3.92 indicated that the respondents agreed that class becomes dull when there is no interaction between them and their teachers. However, the grand mean of 3.45 for all the items indicate that the respondents agreed to a great extent that teacher-learners' interactive feedback helps them in learning effectively.

Answer of Research 2: Items on Classroom Size

Mean and standard deviation was used in answering this question; the result of the analysis is as presented in Table 2:

Table 2: Mean scores of the respondent on Classroom Size ( $=204)$

\begin{tabular}{|c|c|c|c|c|c|c|c|c|}
\hline $\mathrm{S} / \mathrm{N}$ & Classroom Size & $\mathrm{SA}$ & A & $\mathrm{D}$ & SD & M & $\mathrm{SD}$ & Remark \\
\hline 7. & $\begin{array}{l}\text { Our classroom is too small for demonstration } \\
\text { learning }\end{array}$ & 44 & 312 & 138 & 20 & 3.24 & 0.73 & Agreed \\
\hline 8. & $\begin{array}{l}\text { Our Classroom is very large to enhance } \\
\text { dramatizing lesson }\end{array}$ & 96 & 294 & 122 & 21 & 3.62 & 0.95 & Agreed \\
\hline 9. & $\begin{array}{l}\text { Our classroom is spacious; it allows free flow } \\
\text { of air to enhance effective demonstration } \\
\text { learning. }\end{array}$ & 72 & 336 & 114 & 17 & 3.73 & 0.78 & Agreed \\
\hline 10. & $\begin{array}{l}\text { Small classroom space is usually too stuffy to } \\
\text { facilitate effective demonstration learning. }\end{array}$ & 252 & 267 & 58 & 23 & 3.65 & 0.76 & Agreed \\
\hline 11. & $\begin{array}{l}\text { Our spacious classrooms are well illuminated, } \\
\text { which Facilitates successful demonstration } \\
\text { learning. }\end{array}$ & 240 & 276 & 80 & 12 & 3.85 & 0.75 & Agreed \\
\hline \multirow[t]{2}{*}{12.} & $\begin{array}{l}\text { Our classrooms are too dark for meaningful } \\
\text { learning through demonstration methods. }\end{array}$ & 208 & 294 & 66 & 21 & 3.66 & 0.69 & Agreed \\
\hline & Cluster Mean & & & & & 3.63 & 0.78 & Agreed \\
\hline
\end{tabular}

Data in Table 2 show the mean response of students on their classroom size. The mean score of 3.24 for item 7 indicates that the respondents agreed that they learn less because of how small their class is. The mean score of 3.62 for item 8 indicate that the respondents agreed that they learn faster because of their classroom is large for dramatizing due lessons. Item 9 with a mean score of 3.73 also indicates that the respondents agreed that spacious classroom enhanced free airflow. The mean score of 3.65 for item 10 indicate that, the respondents agreed that small classroom is too stuffy for effective learning. The means score of 3.85 for items 11 indicate that, the respondents agreed that illuminated classroom aids there learning. Item 12 with mean score of 3.66 also indicates that, the respondents agreed that their classroom is dark and as such they can't learn effectively. However, the grand mean of 3.63 for 
all items indicate that the respondents agreed to a great extent agreed that their classroom size is one of the factors that aid their learning to be effective.

\section{Answer of Research 3: Items on Availability of Learning Facilities}

Mean and standard deviation was used in answering this question; the result of the analysis is as presented in table 3:

Table 3: Mean scores of the respondent on Availability of learning Facilities (N=204)
S/N $\begin{aligned} & \text { Availability of Learning Facilities } \\ & \text { Modern encyclopedia in the school library }\end{aligned}$
$\begin{aligned} & \text { motivated me to develop private study } \\ & \text { timetable for English language and other }\end{aligned}$
$\begin{aligned} & \text { subjects. } \\ & \text { Chemicals in the chemistry laboratory }\end{aligned}$

Data in Table 3 shows the mean response of students on their availability of learning facilities. The mean score of 3.12 for item 13 indicates the respondents agreed that Modern encyclopedia motivates them to have private study timetable. The mean score of 3.54 for item 14 indicates that the respondents agreed that chemical in the chemistry laboratory attract them to learn chemistry. Item 15 with a mean score of 3.65means that the respondents agreed that a well equip physic laboratory encouraged them to makes physics their best subject. Item 16 with a mean score of 3.78 indicates that the respondents also agreed that update of biology laboratory in their school attracts them to be serious in learning biology. Item 17 with means score of 3.79 indicates that the respondents also agreed that geography garden in their schools make them understand geography. Item 18 with a mean score of 3.85 means that the respondents agreed that availability of counting aids makes them to be proficient in mathematics. However, the grand mean of 3.62 for all items indicate that the respondents to a great extent have a positive attitude towards the availability of learning facilities. 


\section{Answer of Research 4: Items on School Location}

Mean and standard deviation was used fin answering these questions; the result of the analysis is as presented in table 4:

Table 4: Mean scores of the respondent on Availability of learning Facilities (N=204)

\begin{tabular}{|c|c|c|c|c|c|c|c|c|}
\hline $\mathrm{S} / \mathrm{N}$ & Availability of Learning Facilities & SA & A & $\mathrm{D}$ & SD & M & $\mathrm{SD}$ & Remark \\
\hline 13 & $\begin{array}{l}\text { Modern encyclopedia in the school library } \\
\text { motivated me to develop private study } \\
\text { timetable for English language and other } \\
\text { subjects. }\end{array}$ & 81 & 321 & 96 & 22 & 3.12 & 1.17 & Agreed \\
\hline 14. & $\begin{array}{l}\text { Chemicals in the chemistry laboratory } \\
\text { attracted my interest to learn chemistry on } \\
\text { daily basis. }\end{array}$ & 248 & 354 & 28 & 10 & 3.54 & 0.82 & Agreed \\
\hline 15. & $\begin{array}{l}\text { A well-equipped school physics laboratory } \\
\text { encourages me to like physics as my best } \\
\text { science subject. }\end{array}$ & 96 & 396 & 76 & 10 & 3.65 & 1.15 & Agreed \\
\hline 16. & $\begin{array}{l}\text { An updated biological laboratory in my } \\
\text { school attracts me to be serious with biology. }\end{array}$ & 208 & 394 & 66 & 21 & 3.78 & 0.72 & Agreed \\
\hline 17. & $\begin{array}{l}\text { A standard geographical garden in my school } \\
\text { makes me understand geography very } \\
\text { effectively. }\end{array}$ & 252 & 267 & 58 & 23 & 3.79 & 0.65 & Agreed \\
\hline \multirow[t]{2}{*}{18.} & \multirow{2}{*}{$\begin{array}{l}\text { Counting aids in my school encouraged me } \\
\text { to be proficient in mathematics. } \\
\text { Cluster Mean }\end{array}$} & \multirow[t]{2}{*}{276} & \multirow[t]{2}{*}{240} & \multirow[t]{2}{*}{90} & \multirow[t]{2}{*}{10} & 3.85 & 0.75 & Agreed \\
\hline & & & & & & 3.62 & 0.87 & Agreed \\
\hline
\end{tabular}

Data in Table 4 shows the mean response of students on their school location. The mean score of 2.98 for item 19 indicates the respondents agreed that their school is in the town and as such it disturbs their reading attention. The mean score of 3.16 for item 20 indicates that the respondents agreed that their school is in a quiet place and as such they can read for a longer period. Item 21 with a mean score of 3.10 means that the respondents agreed that their school is located near a major road and as such, vehicles noise disturb their reading attention. Item 22 with a mean score of 2.65 indicates that the respondents also agreed that their school is located near a residential quarter and as such, they are not disturb in their reading. Item 23 with means score of 3.14 indicates that the respondents also agreed that their school is located near a popular church and as such, they can't concentrate with their reading. Item 24 with a mean score of 2.92 means that the respondents agreed that their school is located near a market square, therefore, noise disrupts their learning attention. However, the grand mean of 3.15 for all items indicate that the respondents to a great extent agreed that school location is an important factor for an effective learning process. 


\section{Answer of Questions 5: Items on Learning Effectiveness}

Mean and standard deviation was used in answering this question; the result of the analysis is as presented in table 5:

\begin{tabular}{|c|c|c|c|c|c|c|c|c|}
\hline $\mathrm{S} / \mathrm{N}$ & Availability of Learning Facilities & SA & A & $\mathrm{D}$ & $\mathrm{SD}$ & M & $\mathrm{SD}$ & Remark \\
\hline 1. & $\begin{array}{l}\text { My school environment is conducive for } \\
\text { effective learning. }\end{array}$ & 26 & 68 & 270 & 216 & 2.15 & 0.75 & Disagreed \\
\hline 2. & $\begin{array}{l}\text { Seeing life apparatus aids my learning more } \\
\text { effective and make me understood what I } \\
\text { was taught. }\end{array}$ & 328 & 258 & 12 & 30 & 3.16 & 0.69 & Agreed \\
\hline 3. & $\begin{array}{l}\text { The availability of learning facilities } \\
\text { motivated me to learning more. }\end{array}$ & 292 & 252 & 52 & 21 & 3.51 & 0.70 & Agreed \\
\hline 4. & $\begin{array}{l}\text { Learning is fun with interactive and } \\
\text { feedback because it makes me recall and } \\
\text { knows more. }\end{array}$ & 224 & 363 & 32 & 11 & 3.45 & 1.17 & Agreed \\
\hline 5. & $\begin{array}{l}\text { A conducive classroom makes me learn } \\
\text { more. }\end{array}$ & 208 & 294 & 66 & 21 & 2.92 & 0.62 & Agreed \\
\hline 6. & $\begin{array}{l}\text { My classroom size is conducive for effective } \\
\text { learning. }\end{array}$ & 252 & 267 & 58 & 23 & 2.73 & 0.78 & Agreed \\
\hline 7. & $\begin{array}{l}\text { My school location as influenced me } \\
\text { negatively in my academic performance and } \\
\text { learning. }\end{array}$ & 164 & 399 & 48 & 8 & 3.16 & 0.69 & Agreed \\
\hline & Cluster Mean & & & & & 3.01 & 0.77 & Agreed \\
\hline
\end{tabular}

Data in Table 5 shows the mean response of students on their learning effectiveness.

The mean score of 2.15 for item 1 indicates the respondents disagreed that their school environment is not conducive for them for effective learning. The mean score of 3.16 for item 2 indicates that the respondents agreed that seeing life apparatus aids their learning more effective and make them understood what they were taught. Item 3 with a mean score of 3.51 indicates that the respondents also agreed that they learn due to availability of learning facilities. Item 4 with means score of 3.45 indicates that the respondents also agreed that learning is fun because it makes them recall and known more. Item 5 with a mean score of 2.92 indicates that conducive classroom makes them learn more. Item 6 with means score of 2.73 indicates that the respondents also agreed that their conducive classroom size makes them learn effectively. Item 7 with means score of 3.16 indicates that the respondents also agreed that their school location influence them negatively in their academic performance. However, the grand mean of 3.01 for all items indicates that 
the respondents to a great extent have a positive attitude towards learning effectiveness.

\section{Hypothesis Testing}

(Ho1): There is no significant relationship between teacher-learners' interactive feedback and students' learning effectiveness.

Table 6: Dependent t-test analysis of the significant relationship between teacher-learners' interactive feedback and learning effectiveness in $(\mathrm{N}=204)$

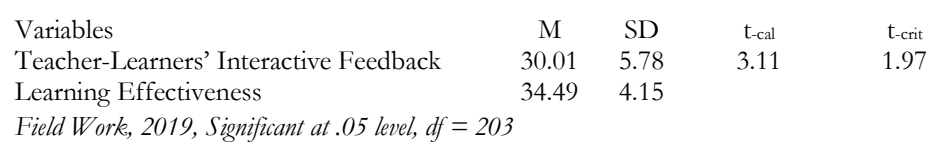

The result as shown in Table 5 indicates that the calculated t-value of 3.11 is greater than the critical t-value of 1.97 at .05 level of significance and 203 degrees of freedom. With this result the null hypothesis that stated that there is no significance relationship between teacher-learners' interactive feedback and students learning effectiveness in Abak local government of Akwa Ibom State was rejected. This implies that there is significant relationship between teacher-learners' interactive feedback and students learning effectiveness in Abak local government of Akwa Ibom State.

(Ho2): There is no significant relationship between of classroom size on students' learning effectiveness.

Table 7: Dependent t-test analysis of the significant relationship between Classroom Size and learning effectiveness $(\mathrm{N}=204)$

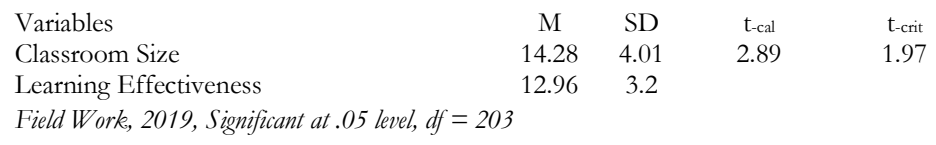

The result as shown in Table 6 indicates that the calculated t-value of 2.89 is greater than the critical t-value of 1.97 at .05 level of significance and 203 degrees of freedom. With this result the null hypothesis that stated that there is no significance relationship between classroom size and students learning effectiveness in Abak local government of Akwa Ibom state was rejected. This implies that there is significant relationship between classroom size and students learning effectiveness in Abak local government of Akwa Ibom State. 
$\left(\mathrm{Ho}_{3}\right)$ : There is no significant relationship between available learning facilities and students' learning effectiveness.

Table 8: Dependent t-test analysis of the significant relationship between availability of learning facilities and students' learning effectiveness in $(\mathrm{N}=204)$

$\begin{array}{lcccr}\text { Variables } & \mathrm{M} & \mathrm{SD} & \mathrm{t}_{\text {-cal }} & \mathrm{t}_{\text {-crit }} \\ \text { Availability of learning facilities } & 15.78 . & 4.71 & 3.02 & 1.97 \\ \text { Learning Effectiveness } & 16.41 & 5.41 & & \\ \text { Field Work, 2019, Significant at .05 level, } d f=203 & & & & \end{array}$

The result as shown in Table 7 indicates that the calculated t-value of 3.02 greater than the critical t-value of 1.97 at .05 level of significance and 203 degrees of freedom. With this result the null hypothesis that stated that there is no significance relationship between availability of learning facilities and students' learning effectiveness in Abak local government of Akwa Ibom State was rejected. This implies that there is significant relationship between availability of learning facilities and students' learning effectiveness in Abak local government of Akwa Ibom State.

(Ho4): There is no significant relationship between school location and students' learning effectiveness

Table 9: Dependent t-test analysis of the significant relationship between of School Location on students' learning effectiveness in $(\mathrm{N}=204)$

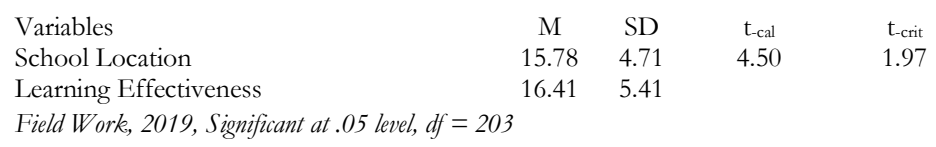

The result as shown in Table 7 indicates that the calculated t-value of 4.50 greater than the critical t-value of 1.97 at .05 level of significance and 203 degrees of freedom. With this result the null hypothesis that stated there is no significance relationship between school location and students' learning effectiveness in Abak local government of Akwa Ibom State was rejected. This implies that there is significant relationship between school location and students' learning effectiveness in Abak local government of Akwa Ibom State.

\section{Discussion of Findings}

This section handled the discussion of findings based on the data analysis and result of this study. 
The result of findings in table 6 revealed that there is significant relationship between teacher-learners of secondary school Two (SS2) students' and their learning effectiveness in Abak local government of Akwa Ibom State.

This result agrees with earlier study done by Asuquo (2006), which claimed stimulated when there is sufficient response of the learners to the teachers' lesson it make the class very interactive and interesting which makes the learners to grasp whatever their teachers is passing across to them. This study also shares the view of Clifford (1972) which states that teachers must interact meaningfully with the learners during lessons to make the learners understand and learn effectively from the lesson. He also stressed that teacher-learners classroom interaction should aimed at making the learners to understand clearly what is taught. Based on the above discussion, it is expected that Senior Secondary School Two (SS2) students in Abak Local Government Area Akwa Ibom State whose teacher-learners' interactive feedback should be strengthen so as to enable them learn effectively.

The result of findings in table 7 revealed that there is significant relationship between classroom size of senior secondary school Two (SS2) students' and their learning effectiveness in Abak local government of Akwa Ibom State.

This result agrees with Essien (2009) who postulated that size of classroom can positively or negatively affect students' learning effectiveness. This finding here is in line with the view of Anderson (1993) who emphasizes that many teachable and learnable school subjects are in-scripted in the syllabus and schemes of work, demand demonstration and dramatic methods In order to carry the learners along during teaching-learning process. Such teaching method demands for large classroom space to enable all the learners participate effectively in the learning. Based on the above discussion, it is inferred that Senior Secondary Two (SS2) Students' in Abak Local Government Area of Akwa Ibom State should be provide with adequate classroom size that can stimulate and accommodate their learning process for effectively learning.

The result of findings in table 8 revealed that there is significant relationship between availability of learning facilities of senior secondary school Two (SS2) students' and their learning effectiveness in Abak local government of Akwa Ibom State. 
This result is in accordance with the views of Ogunlade (2006) who conducted a research on learning environment and educational attainment in some school children in Ogun State revealed that no effective teaching-learning activities can be carried out where appropriate and corresponding learning materials and facilities are lacking. This result also in the line with the view of Denga (2002) who states that, availability of learning facilities is an integral part of learning process, if learning most take place there must be availability of learning facilities to aids effective learning process. Based on the above discussion, it is inferred that Senior Secondary Two (SS2) Students' in Abak Local Government Area of Akwa Ibom State should also be provide with available learning facilities that to aids effective learning.

The result of findings in table 9 revealed that there is significant relationship between school location of senior secondary school Two (SS2) students' and their learning effectiveness in Abak local government of Akwa Ibom State.

This result agrees with Okon (2003) who conducted a research on school location and effects on students' reading attention span in Calabar South locality. The result revealed that conducive school locations, such as noiseless zones promote reading attention span while Unconducive school locations such as those near musical shops, popular churches, market-square and motor parks does not promote reading attention span. The result in this study support the view of John, Miller and Miller, (1985) who states that effective reading cannot be accomplished where external source of noise pollution becomes the reading climate. Based on the above discussion, it is deduced that learning effectiveness of Senior Secondary School Two (SS2) Students in Abak Local Government Area of Akwa Ibom State is significantly influenced by students' school location.

\section{Recommendation}

The following recommendations were made based on the findings of this study:

i) Teachers should select appropriate teaching methods that can encourage the learners' interactive participation.

ii) The government should construct large new classrooms in the secondary schools, while ones should be refurbished to enhance effective academic activities. 
iii) Learning facilities to students be adequately provided by parents and school owners if their children/students to achieve expected academic grades in examinations.

iv) Government and private individual should be mindful of where they erect school buildings to ensure learning effectiveness of their students.

v) School principals should strictly and frequently supervise classrooms when lessons are in progress to ensure teaching-learning effectiveness.

\section{Conclusion}

Based on the results of this study, it can be inferred that there is significant relationship between teachers-learners interactive feedback and classroom size on students' effective learning; Inferably, it was concluded that there is significant relationship between availability of adequate learning facilities and school location on secondary two (SS2) students' learning effectiveness in Abak Local Government Area of Akwa Ibom State.

\section{References}

Anderson, J. R. (1993). Problem Solving and Learning. American Psychologist, 48(1), 35-44

Asuquo, B. B. (2006). Impact of Classroom Climate on Students' Critical Thinking among Senior Secondary School Students in Uyo Metropolis. An unpublished (B. Ed.) Seminar, University of Uyo, Uyo Akwa Ibom State.

Bandele, S. O. (2002). Administration of Continuous Assessment in Tertiary Institution in Nigeria. Journal of Educational Foundations and Management, 1 (1): 289-296.

Clifford, M. M (1972). Effects of Competition as a Motivational Techniques in the Classroom. American educational Research Journal 9 (1), 123-137

Cotton, K. (2001). New Small Learning Communities: Findings from recent literature. Northwest Regional Education laboratory.

Denga, D. I. (2002). Guidance and Counselling in Schools and Non-school Settings. Calabar: Rapid Educational Publisher.

Essien, E. I. (2009). Efficacy of learning Environment and learners' Demonstration. Learning in Urban Local Education Committee. An Unpublished (B.Ed.) Project, Faculty of Education, University of Uyo, Uyo, Akwa Ibom State.

Fraser, B. J (2002). Classroom Learning Environment: Retrospect, Context and prospect. Second International Handbook of Science Education, 1191-1239

Freiberg, H. J (1999). School Climate: Measuring, Improving and Sustaining Healtby Learning Environments: Philadelphia, PA: Falmer Press

Lawal, F. (2003). Students Reference Book on Learning and Remembering Tecbniques. Lagos: Scholastic and Allied Production Ltd. 
Clifford, M. M (1972). Effects of Competition as a Motivational Techniques in the Classroom. American educational Research Journal 9 (1), 123-137

John, H. F, Miller, P. H and Miller, S. A (1985). Cognitive Development. Prentice-Hall

Ogunlade, J. C. (2006). Learning Environment and Educational Attainment in some school children in western Nigeria. Journal of Education, 7, 1-17.

Okon, J. I. (2003). School Location: A correlation of students' reading Attention span. In Calabar south locality. Unpublished (B.Ed.). Project, Faculty of Education, University of Calabar.

Salvin, R. E (1994). Educational psychology: Theory and Practice (London, Aliyn and Bacon).

Sunday, A. T. (2008). Impacts of structured Learning Environment on students' study habits in Mbo Local Government Area. Unpublished NCE, Seminar, Akwa Ibom State College of Education, Afaha Nsit.

\section{Authors}

\section{Abisola Oladeni Sakirudeen}

Researcher, University of Uyo, Faculty of Education, Department of Educational Foundation, Guidance and Counselling, Main Campus, Nwaniba Road, Uyo, Akwa Ibom State, Nigeria, e-mail: abisola4u@gmail.com

Raziskovalec, Univerza v Uyo, Pedagoška fakulteta, Oddelek za izobraževalno fundacijo, usmerjanje in svetovanje, Main Campus, Nwaniba Road, Uyo, Akwa Ibom State, Nigeria, e-pošta: abisola4u@gmail.com

\section{Ekanem Uwe, PhD}

Professor, University of Calabar, Faculty of Education, Department of Educational Foundation, Guidance and Counselling, Cross River State, Etagbor, PMB 1115 Calabar 2018, Nigeria

Profesorica, Ekanem Uwe, Univerza v Calabarju, Pedagoška fakulteta, Oddelek za izobraževalno fundacijo, usmerjanje in svetovanje, Cross River State, Etagbor, PMB 1115 Calabar 2018, Nigeria 
